\title{
Comparison of the Insecticidal Activities of Three Plants against Two Devastating Insects: Callosobruchus maculatus and Sitophilus zeamais
}

\author{
El Hadji Gorgui Diouf',2*, Moussoukhoye Diop¹, Aboubacary Sène¹, Abdoulaye Samb1, Sam Gueye² \\ ${ }^{1}$ Laboratory of Natural Products, Department of Chemistry, Faculty of Sciences and Technological, University Cheikh Anta Diop, \\ Dakar, Senegal \\ ${ }^{2}$ Regional Center for Ecotoxicology Studies and Environment Security (CERES-Locustox), Dakar, Senegal \\ Email: *goorgui82@yahoo.fr
}

How to cite this paper: Diouf, E.H.G., Diop, M., Sène, A., Samb, A. and Gueye, S. (2016) Comparison of the Insecticidal Activities of Three Plants against Two Devastating Insects: Callosobruchus maculatus and Sitophilus zeamais. Open Access Library Journal, 3: e2966.

http://dx.doi.org/10.4236/oalib.1102966

Received: October 29, 2016

Accepted: December 2, 2016

Published: December 5, 2016

Copyright $\odot 2016$ by authors and Open Access Library Inc.

This work is licensed under the Creative Commons Attribution International License (CC BY 4.0).

http://creativecommons.org/licenses/by/4.0/

(c) (i) Open Access

\section{Abstract}

To find the alternate ones with insecticides of synthesis, the extracts of plants are more and more used by the peasants to protect stocks from harvest against the devastating insects. Small fireclay cups phytochimic and insecticidal are made on three plants (Crataeva religiosa, Ficus thonningii and Tapinanthus bangwensis). The identification of the active ingredients present in the three plants show that they contain polyphenols, flavonoides, alkaloids, tannins, saponosides, etc. The insecticidal tests showed that the extract with the chloroform (HEY) of Crataeva religiosa is effective on Callosobruchus maculatus and Sitophilus zeamais while extracts with cyclohexan (EC) and methanolic (EM) are effective only on Callosobruchus maculatus. It sucked shown that the extract with chloroform gives a better mortality rate and that Callosobruchus maculatus is more sensitive to the treatments the strong amount (50 $\mathrm{mg} / \mathrm{mL}$ ). For the study of emergences, the methanolic extract of the sheets of $\mathrm{Cra}$ taeva religiosa ensures a better protection of the medium on Sitophilus zeamais. It was also shown that the extracts with the cyclohexane and methanolic of Ficus thonnigii are more effective on Callosobruchus maculatus. Thus, the methanolic extract (EM) of Ficus thonningii reduces considerably the number of insects emerged in the short run on Callosobruchus maculatus. The tests relating to Tapinanthus bangwensis showed that the extracts cyclohexanic, chloroformic and methanolic are effective on Sitophilus zeamais. The extracts with the cyclohexan and the methanol of Tapinanthus bangwensis reduce considerably the number of insects emerged on Sitophilus zeamais and long-term. Broadly Tapinanthus bangwensis is more effective on the two studied insects and Callosobruchus maculatus is the species most sensitive to the treatments. It is thus the most promising plant. 


\section{Subject Areas}

Plant Science

\section{Keywords}

Plants, Insecticides, Devastating Insects, Stored Food Products

\section{Introduction}

The zones of food insecurity in the world are essentially concentrated inside the tropics. However, these zones neither are exploited nor most fertile of the sphere. To cope with the increasing food request of the populations living in these areas, there exist three possibilities: to slow down the population growth; to increase the agricultural production by increasing the cultivable outputs or surfaces; to reduce the losses before and after harvests [1].

Between harvest and consumption, more than $30 \%$ of the production is lost. This proportion is stronger in sahelian area because of long period of storage [2].

If no protection is made, after seven months of storage, the loss of the food products can be total [3].

To fight against the devastating insects of stocks, the most used method is the use of insecticides of synthesis. According to Isman [4], several developing countries still make recourse to insecticide DDT and other persistent organic pollutants (POP). These pesticides of long persistence ensure the seed protection since the storerooms until in the fields after sowings as well as young seedlings against the insects and the diseases. This causes not only problems of resistance in the devastating insects but, would involve also adverse effects on the environment and the human health.

In the search for alternative methods of fight, the vegetable kingdom offers many possibilities. Many studies currently develop to insulate or identify secondary metabolites extracted from plants which have an insecticidal activity, repulsive or no appetizing with respect to the insects [5].

It is accordingly that our work is registered. Indeed, the insecticidal effect of nine organic extracts (cyclohexanic, chloroformic and methanolic), resulting from three plants, (Crataeva religiosa, Ficus thonnigii and Tapinanthus bangwensis) is tested under the conditions of laboratory on Callosobruchus maculatus (devastating insect of stocks of niebe) and Sitophilus zeamais (devastating insect of corn stocks). These three plants are listed at the time of an ethnobotanic investigation carried out in the department of Mbour. They are used by the local populations in the use and crop protection other.

\section{Materials and Methods}

\subsection{Material}

\subsubsection{Plant Material}

Vegetable material was collected in the rural community of Keur Balla in the depart- 
ment of Mbour, dried in the shade and safe from the light before being conveyed in Dakar for the study. It comprises various types of drugs (barks of stem, sheets) which were crushed and used for the extractions with solvents of gradient of increasing polarities. Vegetable material consists of sheets of Crataeva religiosa, Tapinanthus bangwensis and Ficus thonningii.

\subsubsection{Biological Material}

Biological material relates to Sitophilus zeamaïs and Callosobruchus maculatus obtained by breeding of mass.

\subsection{Methods}

\section{Extraction and Breeding of Mass}

1) Extraction

The technique used for the extractions is the maceration during 24 hours with solvents of gradient of increasing polarity (Cyclohexan, administers chloroform to and Methanol). Indeed, the samples are impregnated in solvents $(1 \mathrm{~g} / 10 \mathrm{~mL})$ of increasing polarity during 72 hours. The extract obtained is concentrated using a rotary evaporator before being dried with the room temperature $\left(25^{\circ} \mathrm{C}\right)$ and safe from the light during 24 to 48 hours. Thus, the diagrams of extraction for the various plants are represented below.

2) Breeding of mass

The breedings of mass relate to Callosobruchus maculatus and Sitophilus zeamais.

Niebe infested was bought at the market on which sorting were operated to recover insects and to launch the breedings of mass. The breedings are launched in jars out of glass of $500 \mathrm{ml}$ of volume approximately. Inside each jar, 20 to 25 insects are introduced and of the impregnated absorbent water cotton to create the conditions of moisture necessary for a good reproduction of the insects. These jars are perforated and covered with fabric of mosquito net to make it possible the insects to breathe. The breedings are made in the shade and the room temperature. Emergences were observed between 17 to 20 days with $C$. maculatus against 28 days with S. zeamais. The tests of insecticidal activity are carried out on insects of first generation constituted by old insects between 0 and 24 hours.

\subsection{Identification of the Chemical Groups}

\subsubsection{Thin Layer Chromatography of Alkaloids}

For the identification of alkaloids, the silica gel is used like stationary phase. Eluant is a mixture of Chloroform and diethylamin $(45 \mathrm{~V} / 5 \mathrm{~V})$. The witness used is Cinchonin. The revelation is made with the reagent of Draggendorf. Red or red colouring orange brand the presence of alkaloids in the extracts. The development is carried out with the room temperature and the atmospheric pressure.

\subsubsection{Thin Layer Chromatography of Tannins}

For the identification of tannins, we used like eluant a mixture of water and methanol, 
ethyl acetate in the respective proportions of $40 \mathrm{ml}, 8 \mathrm{ml}$ and $5 \mathrm{ml}$. For that, plates out of glass covered with silica gel are used like stationary phase. The revelation is made by a ferric chloride solution after drying. Colouring chestnut of the spots is synonymous with the presence of tannins in the extracts. The chromatography is carried out at a temperature of approximatly $25^{\circ} \mathrm{C}$ and the atmospheric pressure.

\subsubsection{Thin Layer Chromatography of the Flavonoides}

For the flavonoids, eluant it used is a mixture of water and ethyl Acetate (15\%). The stationary phase consists of cellulose. The revelation is made with aluminium chloride and the observation under UV with $254 \mathrm{Nm}$. Yellow colouring indicates the presence of flavonoids. In margin of the identification of the flavonoids, could be done that of polyphenols with a direct revelation under UV without use of reagents. Thus, several luminescences are observed with various colourings with the room temperature and safe from the light which show the presence of flavonoids.

\subsubsection{Identification of the Saponosids}

To search the saponosids, $10 \mathrm{ml}$ of the aqueous total extract are versed in a test tube. The tube is agitated during $15 \mathrm{~s}$ then left at rest lasting $15 \mathrm{mn}$. A height of persistent foam, higher than $1 \mathrm{~cm}$ would indicate the presence of saponosids.

\subsection{Biological Test}

The tests relate to three plants (Crateva religiosa, Ficus thonningii and Tapinanthus bangwensis) and two types of insects (Callosobrucus maculatus, ravageur of niebe and Sitophilus zeamaïs, ravageur of corn) and two speculations (niebe and maize). Three extracts of each plant are tested on the two types of insect. Starting from each dry extract, we prepared five solutions with increasing different amounts $(100 \mathrm{mg} / \mathrm{ml}, 2: 50$ $\mathrm{mg} / \mathrm{ml}, 3: 25 \mathrm{mg} / \mathrm{mL}$, 4: $12.5 \mathrm{mg} / \mathrm{mL}$ and $5: 6.25 \mathrm{mg} / \mathrm{mL}$ ). Solution 5 is obtained by taking $1 \mathrm{~g}$ of dry extract which one dissolves in $10 \mathrm{ml}$ of solvent. Solution 4 is obtained by piping $5 \mathrm{ml}$ of the solution 5 which one supplements to $10 \mathrm{ml}$ with solvent. With the same process, we obtained solution 3 starting from solution 4; 2 from the 3 and 1 from the 2 .

The biological tests are carried out in limp of Petri of diameter $90 \mathrm{~mm}$. In each limps, one put $20 \mathrm{~g}$ speculation (niebe or maize). The tests are carried out by pulverizing 500 $\mu \mathrm{l}$ of each solution in the limps of petri thanks to a Pasteur pipette. The test is repeated five times for Sitophilus zeamais and four times for Callosobruchus maculatus. Le The whole is then left with the free air during $20 \mathrm{mn}$ to allow the evaporation of solvent. The insects are introduced thereafter into each limp. On the whole, we used 1215 experimental units to evaluate the toxicity of all the extracts on the insects is 135 units per extract $(135 \times 9=1215)$. The dead insects are sorted and recovered using flexible grips. The number of died, alive and emerged insects are then counted. The formula of Abboth: $\mathrm{Mc}=(\mathrm{Mo}-\mathrm{MT}) /(100-\mathrm{MT}) \times 100$; (with Mc: calculated mortality, Mo: mortality observed and MT: mortality in the pilot batches) is used to correct mortality observed. 


\subsection{Statistical Analysis}

For the data of the biological tests with the extracts of the plant, the measured variables are the number of died insects, the number of surviving insects and the number of emerged insects. Calculated mortality was obtained by applying the formula of Aboth (1925): $\mathrm{Mc}=(\mathrm{Mo}-\mathrm{MT}) /(100-\mathrm{MT}) \times 100$; (where Mo $=$ mortality in the treated batches, $\mathrm{MT}=$ mortality in the witness and $\mathrm{Mc}=$ calculated mortality). The variables many died insects, number of the surviving insects and number of the emerged insects are subjected to a variance analysis, model fixed with three factors (extracted, amounts and time). Variable mortality rate underwent a transformation $\arcsin (\mathrm{X}=$ mortality rate, $\mathrm{N}=$ size of the population; $\mathrm{n}=1999$ ) in order to standardize the population and to stabilize the variance. The general method linear model in Minitab 17 was used for the statistical analysis of the collected data. The variables many surviving insects and many insects emerged as for them underwent a transformation square root in order to standardize the population and to stabilize the varian. The curves and the tables are used to have the result of the analysis.

\section{Results}

\subsection{Extraction Results}

The results of the extractions of the various plants are in Table 1 following.

Table 1 shows that the outputs of the extractions are better for the extracts with the methanol (from 4382 to $11.118 \%$ ) which is a polar solvent. That shows the preponderance of the polar compounds in the studied plants.

\subsection{Phytochemical Study}

The results of the tests of identification, by Thin layer chromatography, of the various chemical groups present in the organic extracts of the three plants (Crataeva religiosa, Ficus thonningii, Tapinanthus bangwensis) are in Table 2.

Table 1. Extraction results.

\begin{tabular}{|c|c|c|c|c|c|}
\hline Plantes & Extracts & Initial mass ( $\mathrm{g}$ ) & $\begin{array}{l}\text { Mass of the } \\
\text { extract (g) }\end{array}$ & Yield (\%) & $\begin{array}{l}\text { Aspect of the } \\
\text { extract }\end{array}$ \\
\hline \multirow{3}{*}{$\begin{array}{l}\text { Crateva } \\
\text { religiosa }\end{array}$} & Hexanic & 195 & 2.8 & 1.436 & Powder \\
\hline & Chloroform & 210 & 2.6 & 1.238 & Powder \\
\hline & Méthanolic & 195.5 & 18 & 9.208 & Pasty \\
\hline \multirow{3}{*}{$\begin{array}{c}\text { Ficus } \\
\text { thonningii }\end{array}$} & Cyclohexanic & 64.352 & 2.733 & 4.247 & Pasty \\
\hline & Chloroformic & 61.619 & 1.391 & 2.257 & Powder \\
\hline & Méthanolic & 60.228 & 2.639 & 4.382 & Pasty \\
\hline \multirow{3}{*}{$\begin{array}{c}\text { Tapinanthus } \\
\text { bangwensis }\end{array}$} & Cyclohexanic & 64.154 & 2.097 & 3.269 & Powder \\
\hline & Chloroformic & 62.057 & 1.414 & 1.279 & Powder \\
\hline & Méthanolic & 60.643 & 6.742 & 11.118 & Pasty \\
\hline
\end{tabular}


Table 2. Results of phytochemical tests.

\begin{tabular}{|c|c|c|c|c|c|c|}
\hline Plants & Extraits & Alcaloids & Flavonoids & Polyphenols & Tannins & Saponosids \\
\hline \multirow{4}{*}{ Ficus thonningii } & Cyclohexanic & + & - & + & - & - \\
\hline & Chloroformic & + & - & + & - & - \\
\hline & Méthanolic & - & + & + & + & - \\
\hline & Aqueous & - & - & - & - & + \\
\hline \multirow{4}{*}{ Crataeva religiosa } & Cyclohexanic & + & + & + & - & - \\
\hline & Chloroformic & + & + & + & + & - \\
\hline & Méthanolic & - & + & + & + & - \\
\hline & Aqueous & - & - & - & - & + \\
\hline \multirow{4}{*}{$\begin{array}{l}\text { Tapinanthus } \\
\text { bangwensis }\end{array}$} & Cyclohexanic & + & - & + & - & - \\
\hline & Chloroformic & + & - & + & + & - \\
\hline & Méthanolic & - & + & + & + & - \\
\hline & Aqueous & - & - & - & - & + \\
\hline
\end{tabular}

+ : présence -: absence.

\subsection{Insecticidal Effects of the Three Plants on Sitophilus zeamais and Callosobruchus maculatus}

Analysis of the variance of the combined insecticidal effects (Table 3) watch which the parameter plant is highly significant $(P<0.001)$. In the same way, the interactions plant-insects are highly significant $(P<0.001)$. The factor insect and the interactions plant-extracts, extract-insects and plant-extract-insects are significant $(P<0.05)$. That implies that mortality depends on the plant, the insects and the extracts. Table 1 and Table 2, Figures 1-4 have the results of the tests combined against $S$. zeamais and $C$. maculatus.

Figure 1 and Figure 2 indicate the curve of mortality according to the plants, the extracts, the amounts and the insects. The plant Tapinanthus bangwensis (P1) is effective on Sitophilus zeamais for the extracts with chloroform and methanol. The plants Crataeva religiosa (P2) and Ficus thonningii (P3) are effective on Callosobruchus maculatus and Sitophilus zeamais for the extracts with cyclohexane, administers chloroform to and methanol with P2 and for the extract methanolic with P3.

Figure 3 and Figure 4 give the curve amongst emerged insects according to the plants, of the extracts, the amounts and the insects. The plant Tapinanthus bangwensis largely reduces the number of emerged insects of $S$. zeamais and $C$. maculatus for the cyclohexanic (EC), chloroformic (EH) and methqnolic (EM) extracts. The plant Crataeva religiosa protects the medium well from treatment against Sitophilus zeamais for the methanolic extract.

\section{Discussion}

The results of the tests phytochimic highlight the presence of alkaloids in the hexanic 


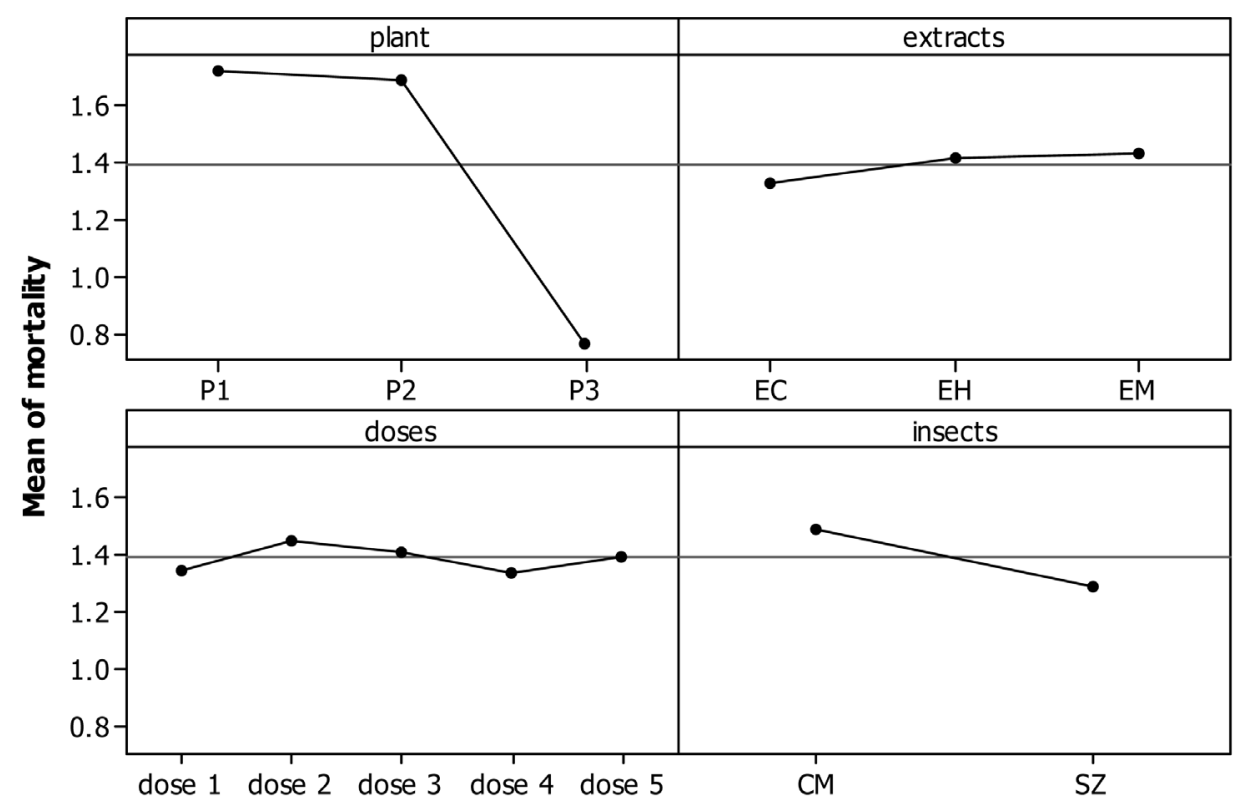

Figure 1. Curve of mortality according to the plants, extracts, amounts and insects.

\section{Plantes}

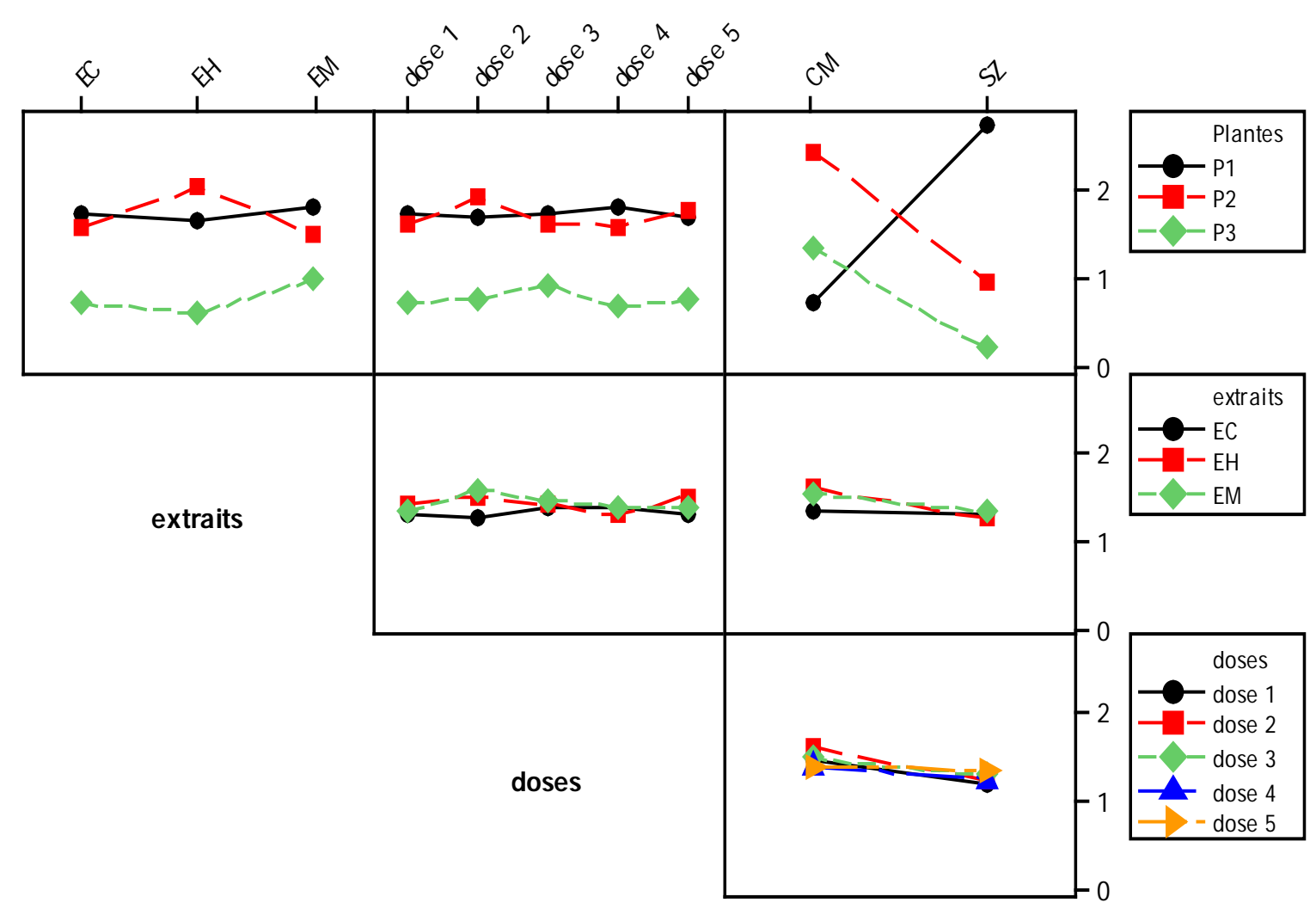

insectes

Figure 2. Interaction between plants, extracts, amounts and insects according to mortality. 


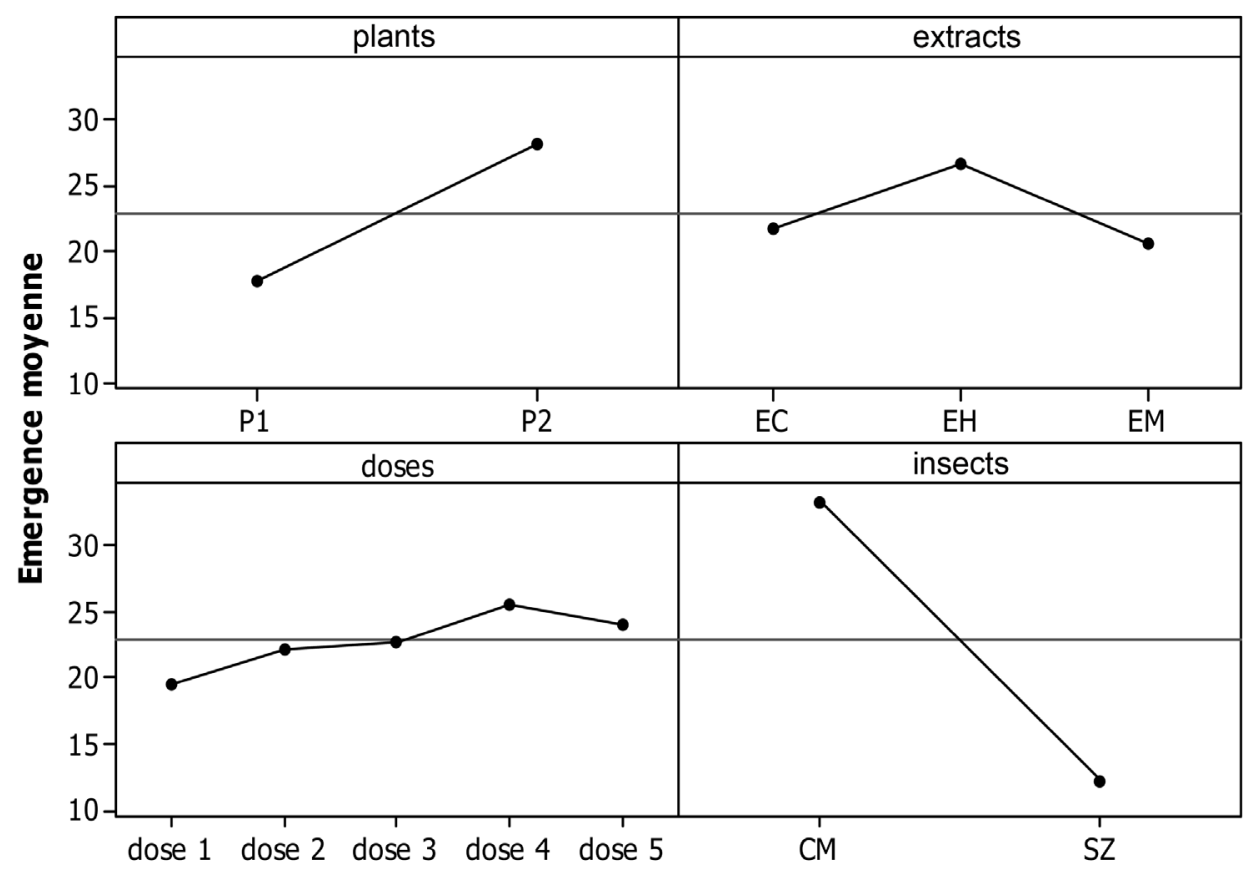

Figure 3. Curve of insects emerged according to the plants, extracts, amounts and insects.

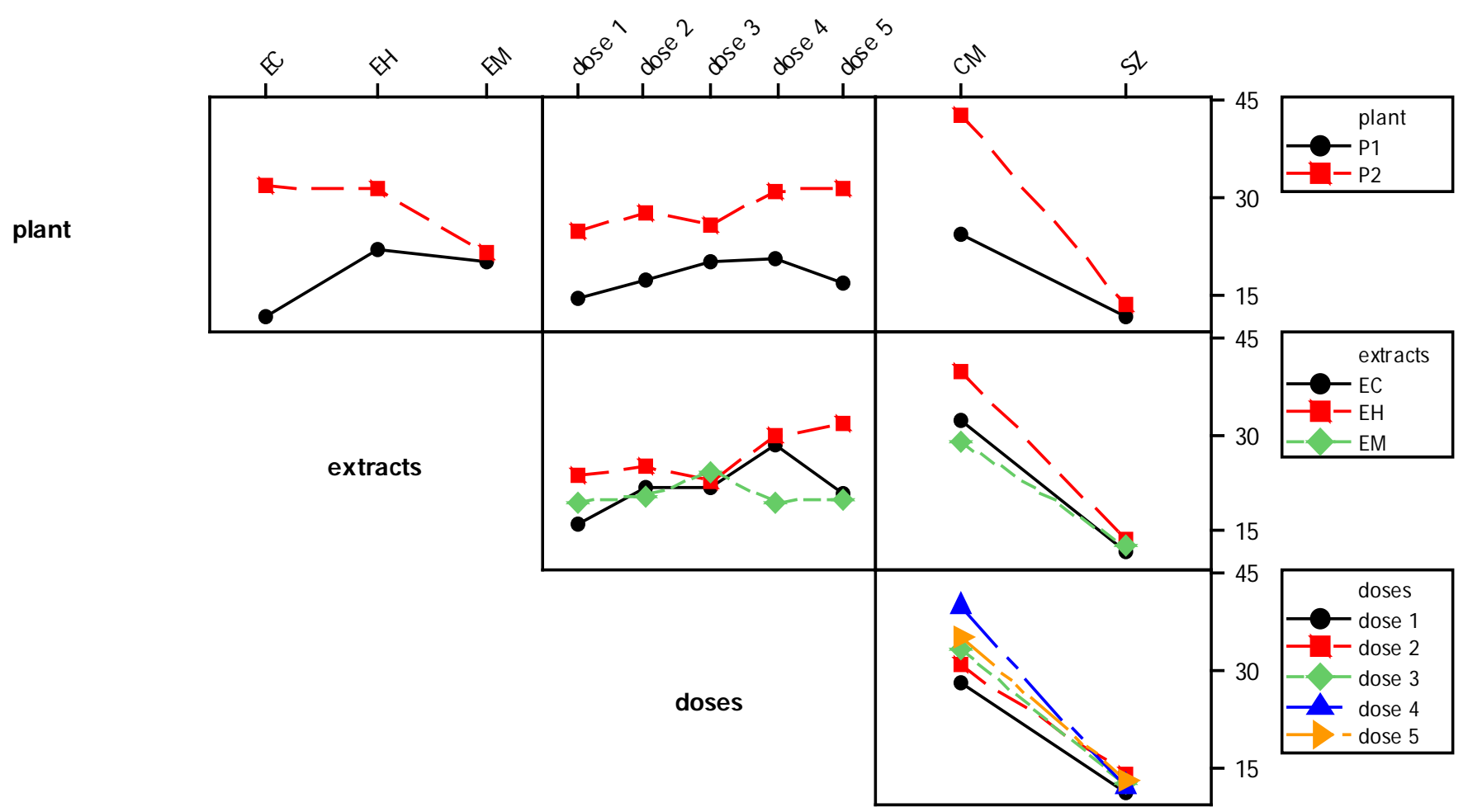

insects

Figure 4. Interaction between plants, extracts, amounts and insects according to the number of emerged insects. 
Table 3. Results of the treatments of the three plants on Sitophilus zeamaïs and Callosobruchus maculates.

\begin{tabular}{ccccccc}
\hline \multirow{2}{*}{ Source de variation } & \multicolumn{3}{c}{ Mortality } & \multicolumn{3}{c}{ Emergency } \\
\cline { 2 - 7 } & $\mathrm{DL}$ & $\mathrm{F}$ & $\mathrm{P}$ & $\mathrm{DL}$ & $\mathrm{F}$ & $\mathrm{P}$ \\
\hline Plants & 2 & 54.60 & 0.000 & 1 & 88.15 & 0.000 \\
Extracts & 2 & 0.55 & 0.576 & 2 & 11.51 & 0.000 \\
Doses & 4 & 0.22 & 0.923 & 4 & 3.84 & 0.004 \\
Insects & 1 & 5.16 & 0.023 & 1 & 363.09 & 0.000 \\
Plants extracts & 4 & 3.06 & 0.016 & 2 & 24.73 & 0.000 \\
Plants doses & 8 & 0.42 & 0.912 & 4 & 1.71 & 0.145 \\
Plants insects & 2 & 149.67 & 0.000 & 1 & 58.25 & 0.000 \\
Extraits doses & 8 & 0.23 & 0.985 & 8 & 3.05 & 0.002 \\
Extraits insects & 2 & 0.97 & 0.381 & 2 & 7.81 & 0.000 \\
Doses insects & 4 & 0.42 & 0.794 & 4 & 3.68 & 0.006 \\
Plantes extracts doses & 16 & 0.25 & 0.999 & 8 & 3.94 & 0.000 \\
Plantes extraits insects & 4 & 2.52 & 0.039 & 2 & 10.62 & 0.000 \\
Extracts doses insects & 8 & 0.27 & 0.976 & 8 & 1.57 & 0.128 \\
Erreur & 4134 & & & & & \\
Total & 4199 & & & & & \\
\hline & & & & & & \\
\hline
\end{tabular}

and chloroformic extracts of Crataeva religiosa, Ficus thonningii and Tapinanthus bangwensis. Flavonoids, polyphenols, tannins and saponosides are also highlighted in the various organic extracts of the various studied plants. Also let us note that the saponosides are only highlighted that in the aqueous extracts.

Several similar studies are corroborated by these results. Among this work, one can quote those of Gowsalya and Saravanababu [6]. They showed the presence of tannins, saponins, flavonoïdes, steroids, glycosides, and alkaloids in the extracts ethanolic, chloroformic and hexanic of Crataeva religiosa.

For Ficus thonningii, several studies carried out by various authors are confirmed by the got results. Ndukwe et al., [7] showed the presence of carbohydrates, glycosides, saponins and alkaloids in the extract methanolic of the sheets, the stems and the roots of Ficus thonningii The studies of Onwkaeme and Udoh [8] highlight the presence of tannins, flavonoïdes, saponins, anthraquinone and glycosides in the sheets of Ficus thonningii.

The results of the tests phytochimic carried out on the species Tapinanthus bangwensis confirmed the work carried out by several authors. Efuntoye et al., [9] identified in the extracts methanolic and chloroformic sheets of Tapinanthus bangwensis the presence of tannins, of alcaloïds, saponins and flavonoids. Of the same Ekhaise et al. [10] identified, in the extract methanolic of the sheets of Tapinanthus bangwensis, various chemical groups such as saponins, the flavonoïdes, of tannins, the steroids and the glycosides. 
The presence of these various families of compounds is likely to give an explanation of the biological activities of the studied plants.

The insecticidal tests showed that the chloroformic extract of Crataeva religiosa is effective on Callosobruchus maculatus and Sitophilus zeamais while extracts with cyclohexan (EC) and methanolic (EM) are effective only on Callosobruchus maculatus. The results also show that the extract with chloroform gives a higher mortality rate and that Callosobruchus maculatus is more sensitive to the treatments. Mortality is higher with the $4 \mathrm{j}, 5 \mathrm{j}, 6$, and $7 \mathrm{j}$. For the study of emergences, the extract methanolic of the sheets of Crataeva religiosa ensures a better protection on Sitophilus zeamais and long-term (33j, $39 \mathrm{j}, 44 \mathrm{j})$.

This study also shows that the extracts with the cyclohexan and methanolic of Ficus thonningii are more effective on Callosobruchus maculatus with 3rd, 4th, 5th, 6th, 7th and 8ej i.e. in the short run.

Thus, the extract methanolic (EM) of Ficus thonningii reduces considerably the number of insects emerged in the short run on Callosobruchus maculatus. For the tests concerning the insecticidal activities of the organic extracts of the sheets of Tapinanthus bangwensis, the extracts cyclohexanic, chloroformic and methanolic of Tapinanthus bangwensis are effective on Sitophilus zeamais. The curve of mortality according to time shows that mortality rate is high with short (1e, 4th, 5th and 7ej) and with long terms (17th and 18ej). We also note that the extracts with the Cyclohexane and the methanol of Tapinanthus bangwensis reduce considerably the number of insects emerged on Sitophilus zeamais and long-term.

In addition, it was shown that the studied plants (Crataeva religiosa, Ficus thonningii and Tapinanthus bangwensis) contain alkaloids, tannins, flavonoids, carbohydrates, glucosides, saponosids and others plyphenols...

The phenolic alkaloids, terpenoids, compounds or the flavonoids are photosynthetats of the plants which variously affect the life or the development cycle of the enemies of the cultures [11].

The higher plants largely produce tannins [12]. Tannins present a toxic direct effect for certain species of insects [13]. Tannins influence the growth, the development and the fertility of several devastating insects. The reduced growth caused by tannins has major drawbacks for the insect, with a lower number of eggs and more a small of eggs, which would affect the survival and the health of the individuals of the subsequent generation [14].

The polyphenols ubiquitaires, in nature, cause a disturbance of the natural motricity of the insect. This one can be fast: as of the first day for quercetin, or later, the fourth day, for the narangine, syringaldéhyde or acid vanillic. It is accompanied in certain cases (cafeic acid and ferulic, vanillin, lutéoline 7-glucoside) by an effect knock down. At the end of eight days all the insects are in a state of coma or dead.

The toxicity of polyphenols is correlated positively by the gravitational power of the compound [15].

Thus the aromatic plants and their allelochimic molecules carry on a double activity: 
-on the adults: by a fast toxic action of type inhalatoire (monoterpenes) on the one hand, and on the other hand by action, which contributes to the insecticidal activity of the aromatic plant of a less intensity but which is exerted in the duration (polyphenols);

-on the various phases of the reproductive cycle: inhibition of the fertility, ovocide activity and larvicide at the stages neonatal and later.

The identified plants are Angiosperms. The Angiosperms contain alkaloids which are secondary metabolites made up by secondary nitrogen atoms, tertiary or quaternary in their structures [16]. They are métaboliquement active and play a significant role in the physiology of the plants or the organizations. The alkaloids have repulsive properties or anti appétantes with regard to the devastating insects [17].

Crataeva religiosa is of the family of Capparidaceae. Several studies showed that species of the family of Capparidaceae showed the insecticidal effect of the organic extracts on the devastating insects of stocks of harvest. Among this work, one can et al. quote those of Gueye [18] [19] which showed the insecticidal activity of Boscia senegalensis on Caryedon serratus (groundnut beetle). It is interesting to mention work of Seck et al. [20] which obtained in direct application of fruits and sheets of $B$. senegalensis to amounts from $2 \%$ to $4 \%(\mathrm{P} / \mathrm{P}) 80$ to $100 \%$ of mortality of the adults of C. maculatus and significantly reduces at the same time the emergence and the damage of F1. Many work also showed that the organic extracts of plants give insecticidal effects on the devastating insects of stored food products. The toxicity of the extracts with organic solvents of Afrostyrax lepidophilus, Trichilia gilgiana, Drypetes gossweileri and Zanha golungensis with regard to Sitophilus zeamaïs, Tribolium castaneum and Rhyzopertha dominica is shown by work of Toumnou [21].

\section{Conclusion}

The results showed that the species Tapinanthus bangwensis is most effective on the two studied insects and that Callosobruchus maculatus is the species most sensitive to the treatments. It is thus the most promising plant. In prospect, the extracts from these plants will be subjected to fractionations and purification in order to isolate to its active principle(s).

\section{References}

[1] Delobel, A. and Tran, M. (1993) Coleopters of the Foodstuffs Stored in the Hot Areas. ORSTOM/CTA. Tropical Fauna 32, Paris, 424 p.

[2] Bell, A., Mück, O. and Schneider, H. (1998) The Integrated Protection of the Stored Food Products Is a Profitable Business! GTZ, Eschborn, Germany, 42 p.

[3] Agounke and Bell, A. (1994) The Code of Practice: Protection of the Stored Food Products Combining the Fractionation of Harvests and the Application of Insecticides. GTZ, Eschborn, Germany.

[4] Isman, M.B. (2006) Botanical insecticides, deterrents, and repellents in modem agriculture and an increasingy regulated world. Annual Review of Entomology, 51, 45-66. https://doi.org/10.1146/annurev.ento.51.110104.151146

[5] Regnault-Roger, C., Philogene, B.J.R. and Vincent, C. (2008) Biopesticides of Vegetable 
Origin. 2nd Edition, Lavoisier, Paris, 550 p.

[6] Gowsalya, P. and Saravanababu (2013) Phytochemical and Antimicrobial Activity of Selected Microorganism of Bark Extract of the Plant Crataeva religiosa. International Journal of Pharmaceutical \& Biological Archives, 1, 179-181.

[7] Ndukwe, I., Bello, A., Habila, J. and John, C. (2007) Phytochemical and Antimicrobial Screening of the Crude Petroleum Spirit and Methanol Extracts of the Stem Bark, Leaves and Roots of Ficus thoningii (Blume). African Journal of Biotechnology, 6, 2645-2649. https://doi.org/10.5897/AJB2007.000-2425

[8] Onwkaeme, D.N. and Et Udoh, F. (2000) Pharmacognostic and Anti-Diarrhoeal Studies of Leaves of Ficus thonningii. Nigerian Journal of Natural Products and Medicine, 4, 27-29. https://doi.org/10.4314/njnpm.v4i1.11733

[9] Efuntoye, M., Ayodele, A., Thomas, B. and Ajay, T. (2010) Does Host Plant Affect the Antibacterial Activity of Tapinanthus bangwensis (Engl. and K. Krause) Danser (Loranthaceae). Journal of Medicinal Plants Research, 4, 1281-1284.

[10] Ekhaise, O., Agboh, M. and Uanseoje, S. (2010) Evaluation of the Methanolic Extract of Mistletoe (Tapinanthus bangwensis) Leaves Grown on Orange Trees for the Phytochemical Properties and Its Physiological Effects on Streptozotocin Induced Diabetes Mellitus in Laboratory Animals. World Applied Sciences Journal, 9, 975-979.

[11] Boeke, S.J., et al. (2004) Safety Evaluation of Neem (Azadirachta indica) Derived Pesticides. Journal of Ethnopharmacology, 94, 25-41. https://doi.org/10.1016/j.jep.2004.05.011

[12] Raymond, V., Barbehenn, C. and Constabel, P. (2011) Tannins in Plant-Herbivore Interactions. Phytochemistry, 72, 1551-1565. https://doi.org/10.1016/j.phytochem.2011.01.040

[13] Vandenborre, G., Smagghe, G. and Van Dammea, J.M. (2011) Plant Lectins as Defense Proteins against Phytophagous Insects. Phytochemistry, 72, 1538-1550. https://doi.org/10.1016/j.phytochem.2011.02.024

[14] Meric, K. (2005) Studies on the Compounds Polyphenolic in Relation to the Food of the Tortrix of the Buds of the Virginal (Choristoneura fumiferana (Clem.). Doctorate, Sciences Forest, Univ. Laval.

[15] Regnault-Roger, C., Ribodeau, M., Hamrauoui, A., Bareau, I., Blanchard, P., Gil, M.I. and Tomas Barberan, F. (2002) Disturbance of Acarthoscelides obtectus (Bruchidae, Cleoptera) Behavior by Polyphenolic Compounds Identified in Insecticidal Labiatae Botanicals. Journal of Stored Products Research (en revision).

[16] Bruneton, J. (2014) Pharmacognosie-Phytochimie, Plantes Médicinales. 6th Edition, Tec \& Doc, Paris, 1288.

[17] Pelletier, S.W. (2001) Alkaloids: Chemical and Biological Perspectives. University of Georgia, Athens, $656 \mathrm{p}$.

[18] Gueye, M.T., Seck, D., Ba, S., Hell, K., Sembene, M., Wathelet, J.-P. and Lognay, G. (2012) Insecticidal Activity of Boscia senegensis (Pers.) Lam ex poir. On Careydon serratus (OI.) Pest of Stored Groundnut. African Journal of Agricultural Research, 6, 6348-6353.

[19] Gueye, M.T., Diallo, Y., Seck, D., Vercammen, J. and Logny, G. (2013) Effects of MITC Released from Boscia senegalensis as Biopesticide in Senegalese Seeds with Special Attention to Cowpea: Detection of Residues. Journal of environment and Ecology, 4, 29-39. https://doi.org/10.5296/jee.v4i1.3903

[20] Gueye, M.T., Seck, D., Ba, S., Hell, K., Sembene, M., Wathelet, J.-P. and Lognay, G. (2012) Insecticidal Activity of Boscia senegensis (Pers.) Lam ex Poir. on Careydon serratus (OI.) Pest of Stored Groundnut. African Journal of Agricultural Research, 6, 6348-6353. 
[21] Lucie, A.T. (2013) Integrated Management of the Principal Devastating Insects of Cereals by the Use of the Secondary Metabolites of the Indigenous Plants of Senegal and Central Africa. Doctorate, SEV, UCAD, 160.

Submit or recommend next manuscript to OALib Journal and we will provide best service for you:

- Publication frequency: Monthly

- 9 subject areas of science, technology and medicine

- Fair and rigorous peer-review system

- Fast publication process

- Article promotion in various social networking sites (LinkedIn, Facebook, Twitter, etc.)

- Maximum dissemination of your research work

Submit Your Paper Online: Click Here to Submit

Or Contact service@oalib.com 